\title{
A Pilot Study of Gene/Gene and Gene/Environment Interactions in Alzheimer Disease
}

\author{
Nader Ghebranious, PhD; Bickol Mukesh, PhD; Philip F. Giampietro, MD, PhD; Ingrid Glurich, PhD; \\ Susan F. Mickel, MD; Stephen C. Waring, PhD; and Catherine A. McCarty, PhD, MPH
}

\begin{abstract}
Background: Although some genes associated with increased risk of Alzheimer Disease (AD) have been identified, few data exist related to gene/gene and gene/environment risk of AD. The purpose of this pilot study was to explore gene/gene and gene/environment associations in AD and to obtain data for sample size estimates for larger, more definitive studies of AD.
\end{abstract}

Methods: The effect of gene/gene and gene/environment interaction related to late onset Alzheimer Disease (LOAD) was investigated in 153 subjects with LOAD and 302 gender matched controls enrolled in the Personalized Medicine Research Project, a population-based bio-repository. Genetic risk factors examined included APOE, ACE, OLR 1, and CYP46 genes, and environmental factors included smoking, total cholesterol, LDL, HDL, triglycerides, C-reactive protein, blood pressure, statin use, and body mass index.

Results: The mean age of the cases was 78.2 years and the mean age of the controls was 87.2 years. APOE4 was significantly associated with $\operatorname{LOAD}(\mathrm{OR}=3.55,95 \% \mathrm{CL}=1.70,7.45)$. Cases were significantly more likely to have ever smoked cigarettes during their life $(49.3 \%$ versus $38.4 \%, p=0.03)$. The highest recorded blood pressure and pulse pressure measurements were significantly higher in the controls than the cases (all $P<0.005$ ). Although not statistically significant in this pilot study, the relationship of the following factors was associated in opposite directions with LOAD based on the presence of an APOE4 allele: obesity at the age of 50, ACE, OLR1, and CYP46.

Conclusions: These pilot data suggest that gene/gene and gene/environment interactions may be important in LOAD, with APOE, a known risk factor for LOAD, affecting the relationship of ACE and OLR 1 to LOAD. Replication with a larger sample size and in other racial/ethnic groups is warranted and the allele and risk factor frequencies will assist in choosing an appropriate sample size for a definitive study.

\footnotetext{
Keywords: ACE; APOE; Biobank; Body mass index; CYP46; Alzheimer Disease; Late onset; OLR 1; Smoking
}

\begin{abstract}
A zheimer Disease (AD [MIM 104300]) is a common, complex genetic disorder with a prevalence rate of $5 \%$ to $10 \%$ and an incidence that increases exponentially after the age of 65 years. A majority of AD cases manifest as sporadic late onset form (LOAD [MIM 606626]), typically with onset above the age of 65 years.
\end{abstract}

Clinical manifestations of the disease are associated with alterations in some or all of the following neurotransmitter networks: the forebrain cholinergic system, noradrenergic system, and telencephalon somatostatinergic system. ${ }^{1}$ In addition, the interaction of cholesterol metabolism, inflammatory processes, and $A P O E$ has been implicated in contributing to the pathogenesis and/or progression of the disease.

Because evidence of genomic variation in association with LOAD is increasingly emerging in both mutational and 
susceptibility loci, it is becoming increasing clear that complex neurodegenerative processes underlie development and susceptibility to LOAD. More recently a large number of genes have been implicated as a risk to LOAD, but only a few of these associations have been replicated. ${ }^{2-4}$

Besides APOE4, which is currently the most established and validated genetic risk factor for LOAD in most populations, ${ }^{5}$ the $A C E$ gene has emerged as another potential risk factor for LOAD. Specifically, the A262T polymorphism (rs4291) in the promoter region of the $A C E$ gene showed strong association with LOAD and was present in up to $35 \%$ of subjects with AD in five independent populations representing approximately 3,100 individuals. $^{6}$ Moreover, recent meta-analysis has determined a highly significant association of a $289 \mathrm{bp}$ Alu insertion/deletion-polymorphism (I/D) in intron 15 of the $A C E$ gene for patients with $\mathrm{AD} .^{6,7}$

Another interesting candidate gene is the oxidized lowdensity lipoprotein (LDL) receptor gene $(O L R 1){ }^{8}$ Three novel sequence variations in the OLR1 gene (chromosome 12) exhibiting strong association with LOAD have been described in intron 4 (rs391640 [GG]), intron 5 (rs2742113 [TT]) and 3' untranslated region (rs1050283 [TT]). All three polymorphisms demonstrated significant association with $\mathrm{AD}$ after stratification for $A P O E 4$ following screening of 800 $\mathrm{AD}$ cases and 700 controls (odds ratio [OR] 2.39, confidence interval [CI] 1.34-4.27), $P=0.0033$; OR 2.11, CI 1.18-3.78, $P=0.012$; OR 2.63, CI 1.44.71, $P=0.0012$, respectively).

Further, CYP46 (chromosome 14q) is the gene encoding cholesterol 24-hydroxylase. The function of this molecule is hydroxylation of cholesterol, a prerequisite to its removal from brain. Recent studies demonstrated that CYP46 (rs754203) is associated with increased $\beta$-amyloid load in brain and cerebral spinal fluid. ${ }^{9}$

As with most complex diseases, LOAD is likely to be influenced not only by genetic, but also by environmental components. ${ }^{10,11}$ Based on outcomes of studies in twins, Plassman et $\mathrm{al}^{12}$ reported simple heritability estimates among various European populations at approximately 0.8, suggesting that environmental factors account for approximately $20 \%$ of variance in population susceptibility to AD.

One environmental factor whose role in $\mathrm{AD}$ pathogenesis remains controversial based on systematic review of casecontrol and cohort studies is smoking history. ${ }^{13-15}$ Several studies have demonstrated that smoking is inversely proportional to $\mathrm{AD}$ progression as a risk factor due to the demonstrated ability of nicotine to stimulate neurotransmitter systems that are compromised in AD. Others have defined potential risk, especially in association with heavy smoking. ${ }^{15-17}$

Another important environmental factor implicated in AD is cholesterol. Increased serum concentrations of total cholesterol, low density lipoprotein (LDL) cholesterol and $A P O E$ have been reported in patients with $\mathrm{AD} .{ }^{18-20}$ Although cholesterol has been implicated in contributing to disease progression and etiology, and numerous hypotheses have been advanced to explain its role in disease pathogenesis, how $A P O E$ or other candidate genes investigated here mechanistically promote etiology, progression, or pathology remains to be defined.

The influence of environmental factors is further emphasized in a recent study of 4,615 subjects where authors reported significant association of increasing age, less education, and presence of APOE4 allele with $\mathrm{AD}$, and decreased risk in association with use of non-steroidal anti-inflammatory drugs, daily coffee consumption, wine consumption, and regular physical activity. The study was unable to demonstrate significant association with respect to family history of dementia, smoking, gender, depression history, estrogen use, hypertension, or cardiovascular conditions. However, while the authors adjusted for gender, education, and age, no adjustment was made for the genotype; thus it is unclear whether risk of other factors was influenced by presence of the APOE4 allele or other candidate genes proposed for $\mathrm{AD}^{21}$

Using a defined population cohort from the Personalized Medicine Research Project (PMRP) this study examined polymorphisms in the $A P O E, A C E, O L R 1$, and CYP46 genes, as well as the effect of several environmental factors, including smoking, cholesterol, triglycerides, C-reactive protein (a marker for inflammation), and blood pressure in order to explore potential interactions of environmental factors and genes in index cases and controls. ${ }^{22}$

\section{Material and Methods}

Personalized Medicine Research Project (PMRP)

The current study was conducted using a nested case-control design utilizing DNA and phenotypic data from a subset of participants in the PMRP cohort, details of which have been published previously. ${ }^{22}$ The PMRP is a population-based biobank located in central Wisconsin. Nearly 20,000 residents aged 18 years and older have participated, consenting to medical record access for purposes of defining phenotype and provision of a blood sample from which DNA, plasma, and serum were extracted and banked. The study was approved by the Marshfield Clinic Institutional Review Board, and all subjects, or their medical power of attorney, gave written informed consent prior to study participation.

\section{Phenotyping of Cases and Controls}

For the present study, the Marshfield Clinic medical records were searched electronically to identify potential cases of AD and controls. Chart abstraction was used to confirm case status and the required inclusion criterion of age $\geq 65$ years at diagnosis. The LOAD diagnosis of cases was made using National Institute of Neurological and Communicative Diseases and Stroke/Alzheimer Disease and Related Disorders 
Table 1. Assay primers and expected product sizes.

\begin{tabular}{|c|c|c|c|c|c|c|c|}
\hline Gene & SNP ID & $\begin{array}{l}\text { Variant (UCSC } \\
\text { genome } \\
\text { browser) }\end{array}$ & Forward & Reverse & Extension primer & $\begin{array}{l}\text { Amplicon } \\
\text { length (bp) }\end{array}$ & $\begin{array}{l}\text { Terminator } \\
\text { mix }\end{array}$ \\
\hline$A P O E$ & rs429358 & $\mathrm{C} / \mathrm{T}$ & TCGCCGCGGTACTGCACCA & CTGTCCAAGGAGCTGCAGG & CGGACATGGAGGACGTG & 106 & ACG \\
\hline$A P O E$ & rs7412 & $\mathrm{C} / \mathrm{T}$ & CTCGCGGATGGCGCTGAGG & TCCGCGATGCCGATGACCTG & CCGATGACCTGCAGAAG & 112 & ACG \\
\hline$A C E$ & rs1800764 & $\mathrm{C} / \mathrm{T}$ & GAGTCTTGGAATGTACCCAC & AACCCATGGGATGAGAGAAG & ATTTGCAAAGTATGTACAGCA & 100 & ACT \\
\hline$A C E$ & rs4291 & $\mathrm{A} / \mathrm{T}$ & TCGGGTGTTCCGGCAAACTG & GCAGAGGAAGCTGGAGAAAG & AAGGGCCTсCTCTCTTT & 91 & CGT \\
\hline$A C E$ & rs4646994 & (289bp Alu)/- & $\begin{array}{l}\text { GGCCATCACATTCGTCAGAT } \\
\text { AGCGAGACTCCGTCTCAAAA }\end{array}$ & GАССАСТСССАТССТTTСТC & ggaTGCCTATACAGTCACTTTT & $\begin{array}{l}201 \text { (del) } \\
104 \text { (ins) }\end{array}$ & iplex \\
\hline$A C E$ & rs4343 & $\mathrm{A} / \mathrm{G}$ & CATGCCCATAACAGGTCTTC & CCTACCAGATCTGACGAATG & GACGAATGTGATGGCCAC & 83 & АCT \\
\hline OLR1 & rs3912640 & $A / G$ & CACAGCAGAGGAATTGAGAC & AACCTGAAACAGACACCCAC & ACTATTAGTAGGAAATGTCATTAG & 112 & ACG \\
\hline OLR1 & rs2742113 & $\mathrm{A} / \mathrm{C}$ & ACACTCTAGAAGCCAGTAAG & GTGTGTTAGACTCCACAAATG & GAAGATAGAAACTTGACAGG & 118 & ACT \\
\hline OLR1 & rs1050283 & $\mathrm{C} / \mathrm{T}$ & CCTGGCACCTTTATGTCAAC & AAGCTTGGGACAAGCTAGGT & AAGCTAGGTGAAATAATACAG & 90 & iplex \\
\hline CYP46 & rs754203 & $A / G$ & CTACCAAAAGAGTGCTGTCC & ACATGACTCGGCAAGTGAGC & GGCAGAGCCTTGCCCCC & 99 & ACG \\
\hline$A M G$ & & (6bp ins/del) & ССТСАTCCTGGGCACCCTGG & GGCTTGAGGCCAACCATCAG & GGACCACTTGAGAAAC & $\begin{array}{l}230(X) \\
236(Y)\end{array}$ & ACG \\
\hline
\end{tabular}

Amplicon length includes the added 10-mers tail. The small letters in the extension primer for the ACE ins/del were added to improve mass discrimination in the multiplex reaction.

SNP, single nucleotide polymorphism.

Association (NINCDS-ADRDA) criteria. ${ }^{1}$ Exclusion criteria included non-genetic causes for dementias and other conditions that make the diagnosis of $\mathrm{AD}$ less likely or uncertain, such as focal neurological findings. All cases were diagnosed by a single neurologist (SFM), who also reviewed all questionable cases in the study. Gender frequency-matched controls were required to be age 80 years and older to minimize misclassification bias in the controls, as is commonly done for strongly age-related conditions, and to have achieved a score $\geq 27$ on a telephone-administered Mini Mental State Examination (MMSE, Psychological Assessment Resources, Inc). ${ }^{23}$

\section{Data Abstraction}

The highest value for total cholesterol, LDL cholesterol, high density lipoprotein (HDL) cholesterol, diastolic and systolic blood pressures, log highest triglycerides, and highest quartile of C-reactive protein were abstracted from the electronic medical records for cases before diagnosis of $\mathrm{AD}$ was confirmed and for controls before the date of MMSE administration. The highest values were chosen, assuming that they had occurred before administration of any medication to alter these levels. This may lead to overestimations of the actual values, such as occurs with "white coat hypertension," but would only lead to bias if it differentially occurred in the cases or controls. Lifetime smoking information (never smoker, past smoker, present smoker) was collected from the self-administered study questionnaire that PMRP participants complete at the time of their enrollment in PMRP. Statin use was abstracted from the medical records. No other medication use was recorded.

\section{Genotyping}

Primer design: Both the amplification and extension primers were designed using the Assay Designer 2.05-software from Sequenom. This software designs the primers used for amplification and the base extension reactions. It also identifies the appropriate termination mix to use in the homogeneous mass extend (hME) or in the i-PLEX reactions. The amplification primers were designed with a 10-mer tag sequence ACGTTGGATG to increase their mass so that they would fall outside the range of detection of the matrixassisted laser desorption/ionization time-of-flight (MALDIToF) mass spectrometry. The amplification and extension primers and expected product sizes are presented in table 1. The amylogenin gene $(A M G)$ I/D gender-specific marker was typed in all the samples for quality control monitoring.

PCR reaction setup for hME: For the hME reaction, a total of $25 \mathrm{ng}$ of genomic DNA was amplified in a $5 \mathrm{ml}$ reaction containing $0.1 \mathrm{U}$ of HotStar Taq enzyme (Qiagen, Valencia, CA), $1 \mathrm{X}$ of HotStar buffer, $2.5 \mathrm{mM}$ (total) $\mathrm{MgCl}_{2}, 0.2 \mathrm{mM}$ (each) deoxynucleotide triphosphate, and $150 \mathrm{nM}$ of the forward and reverse primers for each assay. The PCR step was initiated with a $95^{\circ} \mathrm{C}$ soak for $15 \mathrm{~min}$, followed by 45 cycles consisting of $95^{\circ} \mathrm{C}$ for $20 \mathrm{sec}, 56^{\circ} \mathrm{C}$ for $30 \mathrm{sec}, 72^{\circ} \mathrm{C}$ for 60 sec, and a final extension of $3 \mathrm{~min}$ at $72^{\circ} \mathrm{C}$.

PCR reaction setup for i-PLEX: A total of $25 \mathrm{ng}$ of genomic DNA was amplified in a $5 \mathrm{ml}$ reaction containing $0.5 \mathrm{U}$ of HotStar Taq enzyme, $1.25 \mathrm{X}$ buffer, $1.6 \mathrm{mM} \mathrm{MgCl} 2,0.5 \mathrm{mM}$ each dNTP and $100 \mathrm{nM}$ of each gene-specific forward and reverse primer. The reactions were prepared in a 384-microtiterplate format. The amplifications were done in thermocyclers equipped with 384 well blocks. Cycling conditions were 15 min at $94^{\circ} \mathrm{C}$ followed by 45 cycles of $20 \mathrm{sec}$ at $94^{\circ} \mathrm{C}, 30 \mathrm{sec}$ at $56^{\circ} \mathrm{C}, 60 \mathrm{sec}$ at $72^{\circ} \mathrm{C}$, and a final extension time of $3 \mathrm{~min}$ at $72^{\circ} \mathrm{C}$.

Shrimp alkaline phosphatase (SAP) reaction: After PCR, the remaining unincorporated dNTPs were dephosphorylated by adding $2 \mu \mathrm{l}$ of the SAP cocktail containing $1.53 \mu \mathrm{l}$ of water, $0.17 \mu \mathrm{l}$ of hME reaction buffer (Sequenom), and $0.3 \mu \mathrm{l}$ of SAP (Sequenom). The 384-well plate was then sealed and 
Table 2. Baseline characteristics of the controls and Alzheimer's Disease cases.

\begin{tabular}{|c|c|c|c|}
\hline Baseline Characteristics & $\begin{array}{l}\text { Controls } \\
(\mathrm{N}=302)\end{array}$ & $\begin{array}{c}\text { Cases } \\
(\mathrm{N}=153)\end{array}$ & $P$ value \\
\hline Age & $87.2 \pm 3.0$ & $78.2 \pm 6.4$ & $<0.001$ \\
\hline Female gender & $198(6 \overline{5} .6 \%)$ & $92(60.1 \%)$ & 0.25 \\
\hline Ever Smoked & $116(38.4 \%)$ & $74(49.3 \%)$ & 0.03 \\
\hline $\mathrm{BMI}$ at age 50 & $25.9 \pm 4.0$ & $27.7 \pm 5.1$ & 0.19 \\
\hline Obese $(\mathrm{BMI} \geq 30)$ at age 50 & $100(5 \overline{2} .9 \%)$ & $49(55.7 \%)$ & 0.67 \\
\hline Total cholesterol & $259.0 \pm 43.3$ & $259.3 \pm 47.1$ & $0.82^{\star}$ \\
\hline Statin use & $146(4 \overline{8} .3 \%)$ & $74(51.6 \%)$ & 0.51 \\
\hline LDL cholesterol & $167.6 \pm 41.1$ & $169.3 \pm 43.9$ & $0.50^{\star}$ \\
\hline HDL cholesterol & $62.9 \pm 17.0$ & $59.5 \pm 16.8$ & $0.08^{*}$ \\
\hline Triglycerides & $203.4 \pm 112.5$ & $234.8 \pm 199.3$ & $0.67^{\star}$ \\
\hline C-reactive protein & $2.6 \pm 4.5$ & $2.3 \pm 3.2$ & $0.66^{\star}$ \\
\hline Diastolic blood pressure & $84.3 \pm 10.1$ & $79 . \overline{3} \pm 9.6$ & $<0.001^{*}$ \\
\hline Systolic blood pressure & $165 . \overline{2} \pm 21.0$ & $152.9 \pm 22.9$ & $<0.001^{\star}$ \\
\hline Pulse pressure & $81.0 \pm 18.7$ & $73.7 \pm 19.3$ & 0.004 \\
\hline
\end{tabular}

* Mann-Whitney U-test. BMI, body mass index. LDL, low-density lipoprotein. HDL, high-density lipoprotein.

placed in a thermal cycler under the following conditions: $37^{\circ} \mathrm{C}$ for $20 \mathrm{~min}, 85^{\circ} \mathrm{C}$ for $5 \mathrm{~min}$, and $4^{\circ} \mathrm{C}$ until hME reaction.

hME reaction: After the SAP treatment, a $2 \mu$ cocktail consisting of $1.728 \mu \mathrm{l}$ water, $0.2 \mu \mathrm{l} \mathrm{hME}$ EXTEND mix containing $10 \mathrm{X}$ buffer and appropriate $\mathrm{d} / \mathrm{ddNTPs}$ (Sequenom), $0.54 \mu \mathrm{l}$ of $10 \mu \mathrm{M}$ each extension primer mix and $0.018 \mu \mathrm{l}$ of $32 \mathrm{U} / \mu \mathrm{l}$ ThermoSequenase (Sequenom) was added. After the hME cocktail addition, the plate was again sealed and placed in a thermal cycler with the following program: $94^{\circ} \mathrm{C}$ for 2 min followed by 55 cycles of $94^{\circ} \mathrm{C}$ for $5 \mathrm{sec}, 52^{\circ} \mathrm{C}$ for $5 \mathrm{sec}$, and $72^{\circ} \mathrm{C}$ for $5 \mathrm{sec}$.

i-PLEX reaction: The extension primers, iPLEX enzyme, iPLEX buffer, and the iPLEX termination mixture of massmodified dideoxynucleotide triphosphates were added to initiate the iPLEX primer extension reaction. This reaction generates allele-specific primer extension products that are one base longer than the original MassEXTEND primer. The EXTEND mixture $(2 \mu \mathrm{l})$ was added to the PCR/SAP mixture $(7 \mu 1)$ for a total volume of $9 \mu$ containing $0.222 X$ iPLEX buffer, 1X iPLEX termination mix, $0.625 \mu \mathrm{M}$ to $1.25 \mu \mathrm{M}$ of each extension primer, and 1X iPLEX enzyme. The extension reaction consisted of a two-step 200 short cycles program consisting of one loop of 5 cycles inside a loop of 40 cycles. The sample was denatured at $94^{\circ} \mathrm{C}$ for $30 \mathrm{sec}$. Strands were then annealed at $52^{\circ} \mathrm{C}$ for $5 \mathrm{sec}$ and extended at $80^{\circ} \mathrm{C}$ for 5 sec. The annealing and extension cycle was repeated 4 more times for a total of five cycles and then looped back to a $94^{\circ} \mathrm{C}$ denaturing step for $5 \mathrm{sec}$ and then entered the 5 cycle annealing and extension loop again. The five annealing and extension steps with the single denaturing step were repeated an additional 39 times for a total of 40 runs, which equated to a total number of 200 cycles.

Nanodispensing and mass spectrometry: Following the hME or the i-PLEX extension reactions, the reaction mix was desalted by adding $20 \mu \mathrm{l}$ of a cationic resin mix $(6 \mathrm{mg})$, SpectroCLEAN (Sequenom). The plate was sealed and placed in a rotating shaker for $10 \mathrm{~min}$ for desalting. Completed genotyping reactions were spotted in nanoliter volumes onto a matrix arrayed silicon chip with 384 elements (Sequenom SpectroCHIP) using the MassARRAY Nanodispenser. SpectroCHIPS were analyzed using the Bruker Autoflex MALDI-ToF mass spectrometer and the spectra were processed using the SpectroTYPER software (Sequenom).

\section{Data Analysis}

All data were entered twice and verified. A de-identified data set was created after merging the genetic, phenotypic, and environmental data. SAS (Cary, NC) was used for the analyses and a $P$ value $<0.05$ was considered statistically significant. Chi-square analysis and $t$-tests were used for univariate analyses, and multivariate logistic regression was employed to identify independent risk factors after adjusting for potential confounders. Haplotype analysis was performed using the HAP-Haplotype Resolution version $3.0^{24}$ (http://research .calit2.net/hap/WebServer.htm).

\section{Results}

Our LOAD cohort was comprised of 153 cases (mean age 78.2 years) and 302 controls (mean age 87.2 years). Both the case and control groups were selected from PMRP and were carefully phenotyped as detailed previously in materials and methods (baseline characteristics in table 2). The percent of $\mathrm{AD}$ cases that had ever smoked cigarettes was significantly higher than controls $(49.3 \%$ versus, $38.4 \%, P<0.03)$. Highest recorded systolic and diastolic blood pressures and pulse pressures were significantly higher in controls than cases (all $P<0.005)$.

A total of ten single nucleotide polymorphisms (SNPs) from four genes were tested for associations with LOAD. Genes tested included APOE (rs429358, rs7412), ACE (rs1800764, rs4291, rs464994 [289bp Alu/-], and rs4343), OLRI 
Table 3. Logistic regression analysis adjusting for age, gender, smoking and pulse pressure.

\begin{tabular}{|c|c|c|c|}
\hline Genotype & $\begin{array}{l}\text { Controls } \\
(\mathrm{N}=302)\end{array}$ & $\begin{array}{l}\text { Cases } \\
(\mathrm{N}=153)\end{array}$ & $\begin{array}{c}\text { Odds ratio } \\
(95 \% \mathrm{Cl})\end{array}$ \\
\hline \multicolumn{4}{|c|}{ rs1800764 (ACE) } \\
\hline$\pi$ & 98 (32.5\%) & $61(39.9 \%)$ & 1.00 \\
\hline CT & $141(46.7 \%)$ & 65 (42.5\%) & $0.83(0.37,1.88)$ \\
\hline $\mathrm{CC}$ & 63 (20.9\%) & 27 (17.7\%) & $1.13(0.43,2.92)$ \\
\hline $\mathrm{CC}+\mathrm{CT}$ & 204 (67.6\%) & $92(60.1 \%)$ & $0.92(0.44,1.94)$ \\
\hline \multicolumn{4}{|l|}{ rs4291 (ACE) } \\
\hline $\mathrm{AA}$ & 117 (38.7\%) & $73(47.7 \%)$ & 1.00 \\
\hline AT & $136(45.0 \%)$ & $61(39.9 \%)$ & $0.81(0.37,1.75)$ \\
\hline TT & $49(16.2 \%)$ & 19 (12.4\%) & $0.82(0.28,2.38)$ \\
\hline $\mathrm{TT}+\mathrm{AT}$ & $185(61.3 \%)$ & $80(52.3 \%)$ & $0.81(0.40,1.66)$ \\
\hline \multicolumn{4}{|c|}{ rs4646994 (ACE) } \\
\hline$\pi$ & $76(25.2 \%)$ & $48(31.4 \%)$ & 1.00 \\
\hline AT & $150(49.7 \%)$ & 71 (46.4\%) & $1.46(0.61,3.51)$ \\
\hline $\mathrm{AA}$ & $76(25.2 \%)$ & $34(22.2 \%)$ & $1.29(0.48,3.47)$ \\
\hline $\mathrm{AA}+\mathrm{AT}$ & 226 (74.8\%) & 105 (68.6\%) & $1.39(0.62,3.16)$ \\
\hline \multicolumn{4}{|l|}{ rs4343 (ACE) } \\
\hline $\mathrm{AA}$ & $73(24.2 \%)$ & $46(30.1 \%)$ & 1.00 \\
\hline$A G$ & 157 (52.0\%) & 72 (47.1\%) & $1.37(0.56,3.33)$ \\
\hline $\mathrm{GG}$ & 72 (23.8\%) & 35 (22.9\%) & $1.63(0.59,4.45)$ \\
\hline$G G+A G$ & $229(75.8 \%)$ & 107 (69.9\%) & $1.45(0.63,3.36)$ \\
\hline \multicolumn{4}{|c|}{ rs3912640 (OLR1) } \\
\hline $\mathrm{GG}$ & 239 (79.1\%) & $116(75.8 \%)$ & 1.00 \\
\hline AG & $58(19.2 \%)$ & 35 (22.9\%) & $1.28(0.53,3.09)$ \\
\hline $\mathrm{AA}$ & $5(1.7 \%)$ & $2(1.3 \%)$ & N/A \\
\hline$A A+A G$ & $63(20.9 \%)$ & $37(24.2 \%)$ & $1.17(0.49,2.77)$ \\
\hline \multicolumn{4}{|c|}{ rs2742113 (OLR1) } \\
\hline $\mathrm{CC}$ & 145 (48.0\%) & 75 (49.0\%) & 1.00 \\
\hline$A C$ & 125 (41.4\%) & $63(41.2 \%)$ & $1.20(0.56,2.57)$ \\
\hline $\mathrm{AA}$ & 32 (10.6\%) & $15(9.8 \%)$ & $0.96(0.29,3.16)$ \\
\hline $\mathrm{AA}+\mathrm{AC}$ & 157 (52.0\%) & 78 (51.0\%) & $1.14(0.55,2.35)$ \\
\hline \multicolumn{4}{|c|}{ rs1050283 (OLR1) } \\
\hline $\mathrm{CC}$ & $86(28.5 \%)$ & $40(26.1 \%)$ & 1.00 \\
\hline CT & $144(47.7 \%)$ & $75(49.0 \%)$ & $1.24(0.54,2.83)$ \\
\hline Tा & 72 (23.8\%) & $38(24.8 \%)$ & $0.72(0.25,2.02)$ \\
\hline $\mathrm{TT}+\mathrm{CT}$ & $216(71.5 \%)$ & 113 (73.9\%) & $1.05(0.48,2.29)$ \\
\hline \multicolumn{4}{|c|}{ rs754203 (CYP46) } \\
\hline $\mathrm{AA}$ & 130 (43.0\%) & $68(44.4 \%)$ & 1.00 \\
\hline$A G$ & 137 (45.4\%) & $67(43.8 \%)$ & $1.33(0.63,2.81)$ \\
\hline $\mathrm{GG}$ & 35 (11.6\%) & $18(11.8 \%)$ & $0.94(0.26,3.37)$ \\
\hline $\mathrm{GG}+\mathrm{AG}$ & $172(57.0 \%)$ & $85(55.6 \%)$ & $1.25(0.61,2.57)$ \\
\hline \multicolumn{4}{|l|}{ APOE4 allele } \\
\hline Absent & 247 (81.8\%) & $61(39.9 \%)$ & 1.00 \\
\hline Present & $55(18.2 \%)$ & $92(60.1 \%)$ & $3.55(1.70,7.45)$ \\
\hline
\end{tabular}

(rs3912640, rs2742113, rs1050283), and CYP46 (rs754203). All SNPs tested were within Hardy-Weinberg equilibrium (data not shown).

As expected, the $A P O E 4$ allele had the strongest association with increased risk to $\mathrm{LOAD}(\mathrm{OR}=3.55,95 \% \mathrm{CL}=1.70,7.45$, [table 3]). Although not statistically significant in this pilot study, all of the SNPs genotyped in the $A C E, O L R 1$, and CYP46 genes exhibited different allele frequencies between cases and controls.
Stratification by APOE4 Status

When stratifying by the presence or absence of the APOE4 allele, obesity at age 50 was found to be positively associated with LOAD only in subjects who carry one or two APOE4 alleles $(P=0.13$, table 4$)$. The direction of a potential association between statin use and LOAD also varied by APOE4 allele status, supporting gene/environment interactions.

For all but one of the OLR1 SNPs, the association between allele frequency and LOAD case/control status was markedly, 
Table 4. Baseline characteristics stratified by presence and absence of APOE4 allele.

\begin{tabular}{|c|c|c|c|c|c|c|}
\hline \multirow[b]{2}{*}{ Baseline Characteristics } & \multicolumn{3}{|c|}{$\begin{array}{l}\text { Presence of one or two copies of } \\
\text { APOE4 allele }\end{array}$} & \multicolumn{3}{|c|}{ No copies of $A P O E 4$ allele } \\
\hline & $\begin{array}{l}\text { Controls } \\
(\mathrm{N}=55)\end{array}$ & $\begin{array}{l}\text { Cases } \\
(\mathrm{N}=92)\end{array}$ & $P$ value & $\begin{array}{l}\text { Controls } \\
(\mathrm{N}=247)\end{array}$ & $\begin{array}{l}\text { Cases } \\
(\mathrm{N}=61)\end{array}$ & $P$ value \\
\hline Age & $86.3 \pm 2.8$ & $77.6 \pm 6.4$ & $<0.001$ & $87.4 \pm 3.0$ & $79.1 \pm 6.4$ & $<0.001$ \\
\hline Female gender & $30(54.6 \%)$ & $48(52.2 \%)$ & 0.78 & $168(68.0 \%)$ & $44(72.1 \%)$ & 0.53 \\
\hline Ever Smoked & $23(41.8 \%)$ & $45(50.0 \%)$ & 0.34 & $93(37.7 \%)$ & $29(48.3 \%)$ & 0.13 \\
\hline Obese $(\mathrm{BMI} \geq 30)$ at age 50 & $15(45.5 \%)$ & $33(62.3 \%)$ & 0.13 & $85(54.5 \%)$ & $16(45.7 \%)$ & 0.35 \\
\hline Statin use & 30 (54.6\%) & $54(58.7 \%)$ & 0.62 & $116(47.0 \%)$ & $25(40.1 \%)$ & 0.40 \\
\hline Total cholesterol & $261.9 \pm 44.1$ & $261.1 \pm 46.4$ & $0.92^{*}$ & $258.4 \pm 43.2$ & $256.7 \pm 48.4$ & $0.72^{\star}$ \\
\hline LDL cholesterol & $177.1 \pm 38.2$ & $169.3 \pm 43.0$ & $0.55^{\star}$ & $165.5 \pm 41.5$ & $169.2 \pm 45.9$ & $0.66^{*}$ \\
\hline HDL cholesterol & $60.5 \pm 14.5$ & $57.7 \pm 17.3$ & $0.28^{*}$ & $63.5 \pm 17.4$ & $62.5 \pm 15.5$ & $0.92^{*}$ \\
\hline Triglycerides & $206.5 \pm 96.9$ & $260.7 \pm 236.4$ & $0.84^{*}$ & $202.8 \pm 115.9$ & $190.1 \pm 97.0$ & $0.57^{*}$ \\
\hline C-reactive protein & $2.5 \pm 3.9$ & $2.7 \pm 3.9$ & $1.00^{*}$ & $2.6 \pm 4.7$ & $1.7 \pm 2.0$ & $0.73^{\star}$ \\
\hline Diastolic blood pressure & $83.1 \pm 10.1$ & $78.2 \pm 10.5$ & $0.02^{*}$ & $84.5 \pm 10.1$ & $81.1 \pm 7.7$ & $0.10^{\star}$ \\
\hline Systolic blood pressure & $161.5 \pm 20.0$ & $151.5 \pm 25.0$ & $0.04^{*}$ & $166.0 \pm 21.2$ & $155.3 \pm 18.9$ & $0.01^{*}$ \\
\hline Pulse pressure & $78.4 \pm 16.8$ & $73.3 \pm 20.0$ & 0.17 & $81.5 \pm 19.1$ & $74.3 \pm 18.3$ & 0.06 \\
\hline
\end{tabular}

although not significantly, different between cases and controls, suggesting gene/gene interactions with $A P O E$ (table 5). The distribution of the $A C E$ alleles also varied by $A P O E 4$ status with a different direction of effect by $A P O E 4$ allele status; however, these findings are not statistically significant because the confidence limits overlap. This is also true for CYP46. For four of the eight markers studied, it appears that the risk allele varies by APOE4 allele status, suggesting gene/gene interactions.

\section{Discussion}

As with other complex diseases, LOAD is not only a genetic disease, but also involves environmental components. In this study a number of genetic and environmental factors were examined to determine their relative contribution to LOAD in our PMRP cohort and to obtain pilot data to estimate needed sample size and staffing for a larger more definitive study. Several important strengths of this cohort are: (1) the homogeneity of the sample population (all subjects were European Caucasians from central Wisconsin with greater than $60 \%$ reporting their ethnicity to be German, (2) the LOAD diagnosis for patients was made by a single neurologist (SFM) using NINCDS-ADRDA criteria ${ }^{1}$, (3) the controls from among the cohort were carefully selected after performing an MMSE to exclude any controls with possible signs of dementia who were older, and (4) a complete medical record including all laboratory testing that was electronically available for each patient in the cohort. The majority of the subjects receive their health care exclusively at Marshfield Clinic. A limitation of the pilot cardiovascular risk factors data is that only one measure was extracted. It is possible that lipids, or other risk factors, are associated with AD at different life points or that medications to lower risk of cardiovascular endpoints may impact LOAD risk.
The $A C E$ gene has been a subject of controversy with respect to its association with $\mathrm{AD}$. Our data confirm that the $A C E$ gene is associated with increased risk to LOAD consistent with the three SNP haplotype TAA reported by Kehoe et al, ${ }^{6}$ not including the Alu I/D polymorphism. More interestingly, the association of the $A C E$ SNPs with LOAD varied by $A P O E 4$ allele status. These pilot data provide preliminary evidence that the $A C E$ gene is an independent risk factor to $\mathrm{AD}$ and that gene/gene interaction is potentially occurring. More recently, Meng et $\mathrm{al}^{25}$ reported a very strong association between the $A C E$ gene and LOAD in an Israeli-Arab community where $A P O E 4$ is in very low prevalence in both non-demented $(2.4 \%)$ and demented subjects $(3.6 \%)$. It is likely, therefore, that in the absence of $A P O E 4$, the $A C E$ gene is a strong risk factor for LOAD. These data further support our finding that the $A C E$ gene is an independent risk factor to AD. Recent cross sectional meta-analysis using thousands of samples established that the $A C E \mathrm{I} / \mathrm{D}$ is associated with LOAD without stratification by $A P O E 4 .^{7}$

We also observed an association between the OLR 1 and LOAD which varied by $A P O E 4$. Again, this finding indicates that $O L R 1$ is an independent risk factor to LOAD and supports the initial finding by Luedecking-Zimmer et al. ${ }^{8}$ Interestingly, Bertram et $\mathrm{al}^{26}$ showed a similar trend, with the APOE4 negative group exhibiting a much smaller $P$ value than other groups (with one or two copies of APOE4). However, since their study only achieved a trend toward significance for association of OLR1 with LOAD in the APOE4 negative group $(P=0.074)$, this finding went unrecognized.

Preliminary evidence indicated that the CYP46 intron 2 (rs754203) gene polymorphism is associated with increased 
Table 5. Logistic regression analysis adjusting for age, gender, smoking and pulse pressure stratified by presence and absence of APOE4 allele.

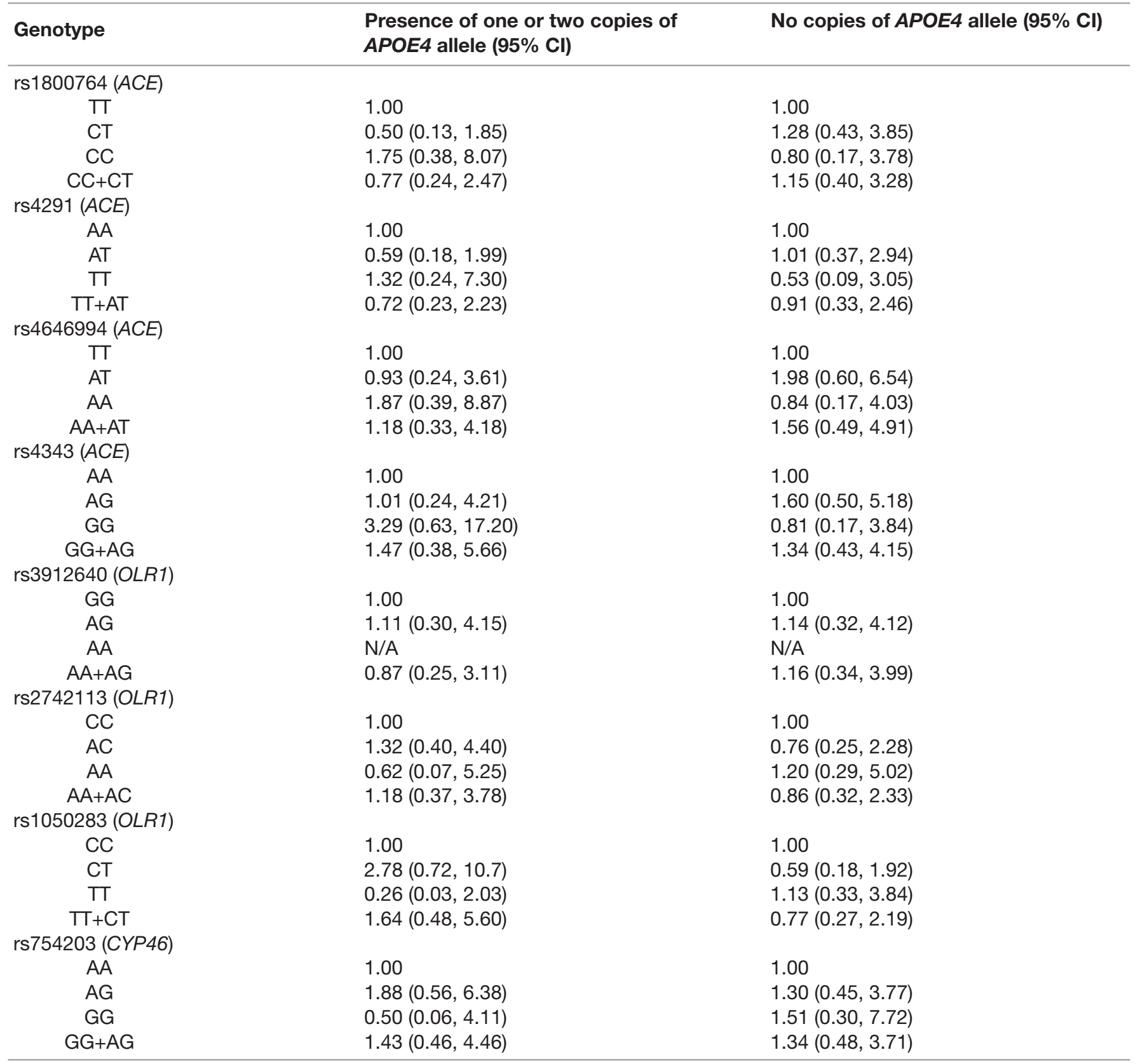

brain $\beta$-amyloid load and higher risk of $\mathrm{AD} .{ }^{9,27-29}$ In our cohort, we found that a potential association between $C Y P 46$ (rs754203) and LOAD varies by APOE4 allele status. Recently a number of other studies in different populations excluded the association of CYP46 (rs754203) with LOAD. ${ }^{30-35}$ It remains possible that such an association exists, and that CYP46 acts synergistically with $A P O E 4$ to increase the risk to LOAD as postulated by some investigators. ${ }^{9,28}$ However, a much larger sample size would be needed to confirm such an interaction.

We analyzed several environmental and personal risk factors before and after stratification by APOE4 allele. After adjustment for the age difference between the cases and controls in multivariate models, blood pressure differences persisted between cases and controls. Smoking showed a positive association with LOAD in subjects without an $A P O E 4$ allele. Our findings pertaining to smoking are in line with previous findings,,${ }^{17,36}$ where the incidence of $\mathrm{AD}$ was shown to be more than double for smokers compared to nonsmokers. Differences in the positive association of smoking and LOAD to studies showing a protective effect of smoking could be due to the stratification of results by APOE4 observed in the current study.

We found obesity at the age of 50 years to be associated with LOAD in subjects who carry an APOE4 allele. A review of the association between dementia and body mass index (BMI) 
concluded that there is sufficient evidence to support an independent relationship of increased BMI as a risk factor for dementia. ${ }^{37}$ Further research to determine if smoking cessation or weight loss results in a decreased risk of LOAD would strengthen these findings.

Identification of genetic risk factors has the potential to lead to both preventative and symptomatic treatment approaches targeting specific biochemical mechanisms supporting pathogenic developments. Currently, the mechanism in which $A P O E, A C E$, and OLRI lead to increased risk for LOAD is unknown, but their definition may lead to development of pertinent models in which the mechanisms for increased risk may be explored. Understanding of mechanisms will lead to therapies targeted at the specific loci in the cascade of pathogenic events leading to LOAD.

In summary, the results from our pilot study suggest that both the $A C E$ and $O L R 1$ genes are risk factors for development of LOAD independent of the APOE4 risk allele, and that gene/ gene and gene/environment interactions exist with APOE4 allele status that need to be accounted for in study design and analysis in future studies of LOAD. The data from this pilot study can be used to estimate sample size and staffing requirements for larger, more definitive studies.

\section{Acknowledgments}

This work was funded by a grant from supporters of Alzheimer Disease research to the Marshfield Clinic Research Foundation (GHE10204). The authors wish to thank Mahala Earnhart, Terrie Kitchner, Jennifer Kislow, Jamie Buettner, and Lynn Ivacic for technical assistance, and Linda Weis and Alice Stargardt for assistance in the preparation of this manuscript.

\section{References}

1. McKhann G, Drachman D, Folstein M, Katzman R, Price D, Stadlan EM. Clinical diagnosis of Alzheimer's disease: report of the NINCDS-ADRDA Work Group under the auspices of Department of Health and Human Services Task Force on Alzheimer's Disease. Neurology 1984;34:939-944.

2. Lehmann DJ, Williams J, McBroom J, Smith AD. Using metaanalysis to explain the diversity of results in genetic studies of late-onset Alzheimer's disease and to identify high-risk subgroups. Neuroscience 2001;108:541-554.

3. Narain Y, Yip A, Murphy T, Brayne C, Easton D, Evans JG, Xuereb J, Cairns N, Esiri MM, Furlong RA, Rubinsztein DC. The ACE gene and Alzheimer's disease susceptibility. J Med Genet 2000;37:695-697.

4. Sanchez-Guerra M, Combarros O, Infante J, Llorca J, Berciano J, Fontalba A, Fernandez-Luna JL, Pena N, FernandezViadero C. Case-control study and meta-analysis of low density lipoprotein receptor-related protein gene exon 3 polymorphism in Alzheimer's disease. Neurosci Lett 2001;316:17-20.

5. Farrer LA, Cupples LA, Haines JL, Hyman B, Kukull WA, Mayeux R, Myers RH, Pericak-Vance MA, Risch N, van Duijn CM. Effects of age, sex, and ethnicity on the association between apolipoprotein $\mathrm{E}$ genotype and Alzheimer disease. A meta-analysis. APOE and Alzheimer Disease Meta Analysis Consortium. JAMA 1997; 278:1349-1356.
6. Kehoe PG, Katzov H, Feuk L, Bennet AM, Johansson B, Wiman B, de Faire U, Cairns NJ, Wilcock GK, Brookes AJ, Blennow $\mathrm{K}$, Prince JA. Haplotypes extending across ACE are associated with Alzheimer's disease. Hum Mol Genet 2003;12:859-867.

7. Lehmann DJ, Cortina-Borja M, Warden DR, Smith AD, Sleegers K, Prince JA, van Duijn CM, Kehoe PG. Large meta-analysis establishes the ACE insertion-deletion polymorphism as a marker of Alzheimer's disease. Am J Epidemiol 2005;162:305-317.

8. Luedecking-Zimmer E, DeKosky ST, Chen Q, Barmada MM, Kamboh MI. Investigation of oxidized LDL-receptor 1 (OLR1) as the candidate gene for Alzheimer's disease on chromosome 12. Hum Genet 2002;111:443-451.

9. Papassotiropoulos A, Streffer JR, Tsolaki M, Schmid S, Thal D, Nicosia F, Iakovidou V, Maddalena A, Lutjohann D, Ghebremedhin E, Hegi T, Pasch T, Traxler M, Bruhl A, Benussi L, Binetti G, Braak H, Nitsch RM, Hock C. Increased brain beta-amyloid load, phosphorylated tau, and risk of Alzheimer disease associated with an intronic CYP46 polymorphism. Arch Neurol 2003;60:29-35.

10. Heininger K. A unifying hypothesis of Alzheimer's disease. III. Risk factors. Hum Psychopharmacol 2000;15:1-70.

11. Heininger K. A unifying hypothesis of Alzheimer's disease. IV. Causation and sequence of events. Rev Neurosci 2000;11 Spec No:213-328.

12. Plassman BL, Breitner JC. Recent advances in the genetics of Alzheimer's disease and vascular dementia with an emphasis on gene-environment interactions. J Am Geriatr Soc 1996;44:1242-1250.

13. Almeida OP, Hulse GK, Lawrence D, Flicker L. Smoking as a risk factor for Alzheimer's disease: contrasting evidence from a systematic review of case-control and cohort studies. Addiction 2002;97:15-28.

14. Lopez-Arrieta JM, Rodriguez JL, Sanz F. Efficacy and safety of nicotine on Alzheimer's disease patients. Cochrane Database Syst Rev 2001:CD001749.

15. Tyas SL, Pederson LL, Koval JJ. Is smoking associated with the risk of developing Alzheimer's disease? Results from three Canadian data sets. Ann Epidemiol 2000;10:409-416.

16. Fratiglioni L, Wang HX. Smoking and Parkinson's and Alzheimer's disease: review of the epidemiological studies. Behav Brain Res 2000;113:117-120.

17. Tyas SL, White LR, Petrovitch H, Webster Ross G, Foley DJ, Heimovitz HK, Launer LJ. Mid-life smoking and late-life dementia: the Honolulu-Asia Aging Study. Neurobiol Aging 2003;24:589-596.

18. Austen B, Christodoulou G, Terry JE. Relation between cholesterol levels, statins and Alzheimer's disease in the human population. J Nutr Health Aging 2002;6:377-382.

19. Petanceska SS, DeRosa S, Sharma A, Diaz N, Duff K, Tint SG, Refolo LM, Pappolla M. Changes in apolipoprotein E expression in response to dietary and pharmacological modulation of cholesterol. J Mol Neurosci 2003;20:395-406.

20. Sparks DL, Lopez J, Connor D, Sabbagh M, Seward J, Browne P; Alzheimer's Disease Cholesterol-Lowering Treatment Team. A position paper: based on observational data indicating an increased rate of altered blood chemistry requiring withdrawal from the Alzheimer's Disease Cholesterol-Lowering Treatment Trial (ADCLT). J Mol Neurosci 2003;20:407-410.

21. Lindsay J, Laurin D, Verreault R, Hebert R, Helliwell B, Hill GB, McDowell I. Risk factors for Alzheimer's disease: a prospective analysis from the Canadian Study of Health and Aging. Am J Epidemiol 2002;156:445-453. 
22. McCarty CA, Wilke RA, Giampietro PF, Wesbrook SD, Caldwell MD. Marshfield Clinic Personalized Medicine Research Project (PMRP): design, methods and recruitment for a large population-based biobank. Personalized Medicine 2005;2:49-79.

23. Folstein MF, Folstein SE, McHugh PR. "Mini-mental state." A practical method for grading the cognitive state of patients for the clinician. J Psychiatr Res 1975;12:189-198.

24. Halperin E, Eskin E. Haplotype reconstruction from genotype data using Imperfect Phylogeny. Bioinformatics 2004;20:1842-1849.

25. Meng Y, Baldwin CT, Bowirrat A, Waraska K, Inzelberg R, Friedland RP, Farrer LA. Association of polymorphisms in the Angiotensin-converting enzyme gene with Alzheimer disease in an Israeli Arab community. Am J Hum Genet 2006;78:871-877.

26. Bertram L, Parkinson M, Mullin K, Menon R, Blacker D, Tanzi RE. No association between a previously reported OLR1 3' UTR polymorphism and Alzheimer's disease in a large family sample. J Med Genet 2004;41:286-288.

27. Combarros O, Infante J, Llorca J, Berciano J. Genetic association of CYP46 and risk for Alzheimer's disease. Dement Geriatr Cogn Disord 2004;18:257-260.

28. Johansson A, Katzov H, Zetterberg H, Feuk L, Johansson B, Bogdanovic N, Andreasen N, Lenhard B, Brookes AJ, Pedersen NL, Blennow K, Prince JA. Variants of CYP46A1 may interact with age and APOE to influence CSF Abeta42 levels in Alzheimer's disease. Hum Genet 2004;114:581-587.

29. Kolsch H, Lutjohann D, Ludwig M, Schulte A, Ptok U, Jessen F, von Bergmann K, Rao ML, Maier W, Heun R. Polymorphism in the cholesterol 24S-hydroxylase gene is associated with Alzheimer's disease. Mol Psychiatry 2002;7:899-902.

30. Desai P, DeKosky ST, Kamboh MI. Genetic variation in the cholesterol 24-hydroxylase (CYP46) gene and the risk of Alzheimer's disease. Neurosci Lett 2002;328:9-12.

31. Golanska E, Hulas-Bigoszewska K, Wojcik I, Rieske P, Styczynska M, Peplonska B, Pfeffer A, Luczywek E, Wasiak B, Gabryelewicz T, Religa D, Chodakowska-Zebrowska M, Barcikowska M, Sobow T, Liberski PP. CYP46: a risk factor for Alzheimer's disease or a coincidence? Neurosci Lett 2005;383:105-108.

32. Ingelsson M, Jesneck J, Irizarry MC, Hyman BT, Rebeck GW. Lack of association of the cholesterol 24-hydroxylase (CYP46) intron 2 polymorphism with Alzheimer's disease. Neurosci Lett 2004;367:228-231.

33. Kabbara A, Payet N, Cottel D, Frigard B, Amouyel P, Lambert JC. Exclusion of CYP46 and APOM as candidate genes for Alzheimer's disease in a French population. Neurosci Lett 2004;363:139-143.

34. Tedde A, Rotondi M, Cellini E, Bagnoli S, Muratore L, Nacmias B, Sorbi S. Lack of association between the CYP46 gene polymorphism and Italian late-onset sporadic Alzheimer's disease. Neurobiol Aging 2006;27:773.e1-3.

35. Wang F, Jia J. Polymorphisms of cholesterol metabolism genes CYP46 and ABCA1 and the risk of sporadic Alzheimer's disease in Chinese. Brain Res 2007;1147:34-38.

36. Ott A, Slooter AJ, Hofman A, van Harskamp F, Witteman JC, Van Broeckhoven C, van Duijn CM, Breteler MM. Smoking and risk of dementia and Alzheimer's disease in a populationbased cohort study: the Rotterdam Study. Lancet 1998;351:1840-1843.

37. Gorospe EC, Dave JK. The risk of dementia with increased body mass index. Age Ageing 2007;36:23-29.

\section{Author Affiliations}

Nader Ghebranious, PhD*; Bickol Mukesh, PhD ${ }^{*}$;

Philip F. Giampietro, MD, PhD*t; Ingrid Glurich, PhD\$;

Susan F. Mickel, MD"/ Stephen C. Waring, PhD\#; and

Catherine A. McCarty, PhD, MPH*

* Center for Human Genetics, Marshfield Clinic Research

Foundation, Marshfield, WI USA

†Alcon Laboratories, Fort Worth, TX USA

IDepartment of Pediatrics, University of Wisconsin, Madison, WI USA

§Office of Research Facilitation, Marshfield Clinic Research Foundation, Marshfield WI, USA

"Department of Neurology, Marshfield Clinic, Marshfield, WI USA

\#Epidemiology Research Center, Marshfield Clinic Research Foundation, Marshfield, WI USA 